\title{
Tilbakemelding og veiledning i høyere utdanning
}

Hva forklarer studentenes misnøye?

Stephan Hamberg, Pål Bakken og Marie-Louise Damen 2016 


\section{Sammendrag}

Utgangspunktet for dette notatet er det interessante paradokset at selv om studentene er misforn $\varnothing \mathrm{yd}$ med tilbakemelding og individuell oppfølging så er de meget tilfredse med kvaliteten i

studieprogrammet sine. Dette er spesielt interessant når vi vet at formative tilbakemeldinger og individuell oppfølging har positive effekter på studentenes tilegnelse av kunnskap og ferdigheter, læring, motivasjon, studiegjennomføring og overordnet tilfredshet. Basert på kvantitative analyser av Studiebarometeret, samt intervjuer på sju studieprogrammer finner vi at studentene har lave forventninger til tilbakemeldinger og veiledning. I tillegg mangler de forståelse for hvor viktig disse faktorene er for deres egen læring og motivasjon.

Analysene viser videre at antall tilbakemeldinger og miljøet mellom faglig ansatte og studenter er faktorer som forklarer mye av studentenes lave tilfredshet med tilbakemeldinger.

Det at studentenes lave tilfredshet med tilbakemelding og veiledning ikke påvirker den overordnede tilfredsheten bør ikke fungere som en sovepute for institusjonene. Studentenes mangel på forståelse av hvor viktig tilbakemelding og veiledning er bør heller føre til at institusjonene gir flere og bedre tilbakemeldinger og veiledninger. De bør også gjøre studentene oppmerksomme på den verdien gode tilbakemeldinger og veiledning har for studentenes læringsutbytte. Dette fokuset bør starte allerede i første studieår.

På NTNU er det tydelig at de innfusjonerte høyskolene har hatt mer fokus på tilbakemelding og veiledning enn studieprogrammene ved «gamle» NTNU. Det er noen naturlige årsaker til dette: mindre studieprogram, mer fokus på undervisning enn forskning og færre master- og doktorgradsstudenter. Vi tror likevel at tallenes klare tale indikerer at faglig ansatte og undervisningsledere ved «gamle» NTNU har noe å lære av de innfusjonerte høyskolene. 


\section{Innhold}

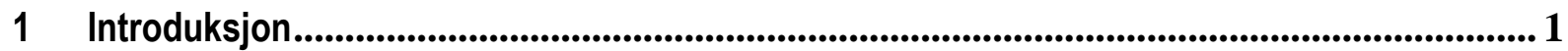

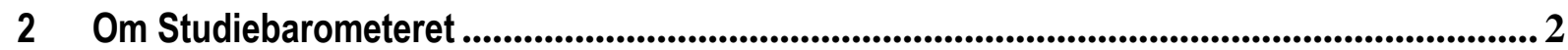

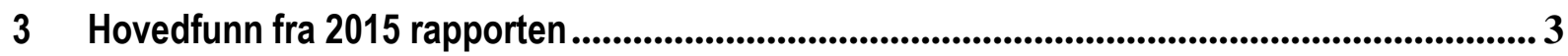

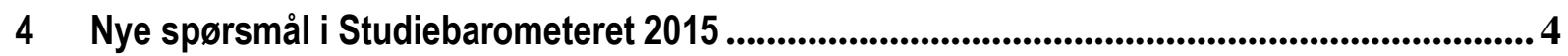

5 Studiebarometeret 2015: Nye analyser .............................................................................................. 6

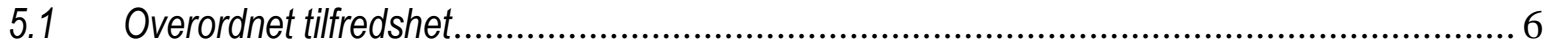

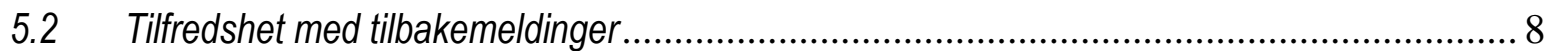

6 Tilbakemelding og veiledning på NTNU ............................................................................ 12

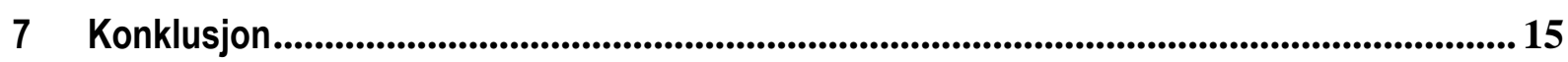




\section{Introduksjon}

Et av formålene med kvalitetsreformen i 2003 var at man ønsket å bedre kvaliteten på utdanning og forskning. Med hensyn til utdanning ønsket man å redusere antall år studentene brukte på å fullføre en universitet eller høyskolegrad. I tillegg ønsket man at universiteter og høyskoler skulle begynne å evaluere studenter på andre måter enn med avsluttende eksamener. Det ble et $\varnothing \mathrm{kt}$ fokus på bruk av evalueringsmetoder som ville gi studenter mulighet til å få formative tilbakemeldinger, for eksempel portfolioevaluering, hjemmeeksamen og obligatoriske oppgaver gjennom studiet. Institusjonene ble også bedt om å $\emptyset$ ke fokuset individuell oppfølging og veiledning gjennom studiet.

Flere evalueringer av kvalitetsreformen har påpekt at norske høyere utdanningsinstitusjoner fortsatte å bruke avsluttende eksamener som den viktigste evalueringskilden av studenter (se for eksempel Michelsen og Aamodt 2007). Et stort antall politikere, studentpolitikere og studentorganisasjoner har i flere år diskutert mangelen på individuell tilbakemelding og oppfølging, men inntil NOKUT gjennomførte den nasjonale studentundersøkelsen Studiebarometeret for første gang i 2013, har vi ikke hatt noe godt empirisk materiale på hvordan norske studenter oppfatter kvaliteten på tilbakemeldinger og oppfølging og hvordan dette påvirker studentenes overordnede tilfredshet med studieprogrammene sine.

Blant de mest interessante funnene i Studiebarometeret i 2013, 2014 og 2015 er at studentene er mindre fornøyde med tilbakemelding og oppfølging fra faglig ansatte enn nesten alle de andre spørsmålene de svarer på. Dette er overraskende når man reflekterer over hvor mye fokus det har vært på tilbakemelding og oppfølging/veiledning i norsk høyere utdanning siden årtusenskiftet. Samtidig er studentene meget tilfredse med den overordnede kvaliteten på studieprogrammene. Det er ikke slik at de studentene som er minst fornøyde med tilbakemelding og oppfølging er minst fornøyde med den overordnede kvaliteten. Det er altså ingen sammenheng mellom disse spørsmålene (svarene). Denne mangelen på sammenheng er også tankevekkende - om ikke direkte overraskende - med tanke på at forskningen er temmelig entydig på at tilbakemeldinger og oppfølging er svært viktig for studentenes motivasjon, læring, gjennomføring og frafall.

Våren 2015 satte NOKUT i gang et utredningsprosjekt for å svare på spørsmålet Hvorfor er studentene så tilfreds med den overordnede kvaliteten når de er misforn $\phi y d e ~ m e d ~ t i l b a k e m e l d i n g e n e$ og oppfølgingen de får? Utredningen kombinerte kvantitative analyser basert på data fra Studiebarometeret fra 2014 og gruppeintervjuer av studenter, faglig ansatte og programledere på sju studieprogrammer i Norge. Utredningen ble publisert som en frittstående rapport (Hamberg et al. 2015) og lagt frem på en internasjonal konferanse. I tillegg ledet utredningen til at flere nye spørsmål ble inkludert i Studiebarometeret 2015. I dette notatet presenterer vi først et kort sammendrag av rapporten fra 2015, deretter beskriver vi kort de nye spørsmålene. Vi presenterer så noen nye kvantitative analyser som nyanserer og i all hovedsak bekrefter funnene fra 2015-rapporten. Til slutt ser vi spesifikt til «nye» NTNU og presenterer noen interessante forskjeller mellom studier på «gamle» NTNU og de innfusjonerte høyskolene. 


\section{Om Studiebarometeret}

Den nasjonale studentundersøkelsen Studiebarometeret gjennomføres av NOKUT. Oppdraget ble gitt NOKUT av Kunnskapsdepartementet i 2012. En del av oppdraget var å presentere resultater fra undersøkelsen på studieprogramnivå i en ny nettportal, noe som resulterte i Studiebarometeret.no.

Studiebarometeret kartlegger studentenes oppfatning av kvaliteten på eget studieprogram og skal gi enkel og brukervennlig informasjon om dette. Informasjonen skal bidra til å styrke arbeidet med kvalitetsutvikling i høyere utdanning og gi studiesøkere og andre nyttig informasjon om opplevd studiekvalitet. Ett av NOKUTs formål er å fremme kvalitet i høyere utdanning. NOKUTs arbeid skal også bidra til at samfunnet kan ha tillit til kvaliteten i norsk høyere utdanning. Studentenes stemme er en viktig indikator på studiekvalitet og Studiebarometeret er et viktig hjelpemiddel for å spre kunnskap om studiekvalitet.

Totalt deltok 57 institusjoner som gir høyere utdanning i undersøkelsen i 2015. Alle universiteter og vitenskapelige høyskoler deltok samt nesten alle private og statlige høyskoler. Til sammen omfattet undersøkelsen ca. 61000 studenter fordelt på ca. 1800 studieprogrammer. Svarinngangen for undersøkelsen høsten 2015 ble $47 \%$ (nesten 29000 svarende studenter).

Studiebarometeret omfatter studieprogram på bachelor- og mastergradsnivå med varighet på minst tre semester som tilbys i Norge. Dette inkluderer «ordinære» bachelor- og mastergradsstudier, samt 4-, 5og 6-årige profesjonsutdanninger som grunnskolelærer, lektorprogram, sivilingeniør, medisin, veterinær etc. Til sammen utgjorde dette 1794 studieprogram i 2015, fordelt på 974 bachelorgradsprogrammer og 820 mastergradsprogrammer.

Alle andre års studenter på bachelor- og mastergradsprogrammer, som er registrert som studenter i høstsemesteret, skal inngå. På lengre profesjonsutdanninger spør vi studenter som er i sitt andre og studenter som er i sitt femte studieår. Undersøkelsen omfatter ikke studenter som er i permisjon.

Spørreskjemaet består av om lag 100 spørsmål og de fleste handler om studentens opplevelse av studiekvaliteten på studieprogrammet sitt. Det ble blant annet spurt om synspunkter på studie- og læringsmilj $\varnothing$, undervisning og veiledning, læringsutbytte og arbeidslivsrelevans. I tillegg besvarte studentene spørsmål om motivasjon, studieinnsats og forventninger. Spørreskjemaet består både av spørsmål og påstander. I det følgende bruker vi begrepet spørsmål om alle. Spørsmålene besvares ved hjelp av en femdelt skala (fra «Ikke tilfreds» til «Svært tilfreds», alternativt «Ikke enig» til «Helt enig») med en vet ikke-kategori. Svarene er gitt verdiene 1-5, studentenes svar er mer positivt jo høyere verdien er.

Spørsmålene er rettet mot studieprogramnivå, ikke emne- eller institusjonsnivå. Det samme skjemaet sendes til alle studenter, uavhengig av type studieprogram. Skjemaet har en stabil kjerne av spørsmål, som utgjør ca. 2/3 av alle spørsmålene. Den siste tredjedelen brukes til alternerende grupper av spørsmål («batterier»), som byttes ut og erstattes av andre. Et eksempel er de ekstra batteriene om tilbakemelding og veiledning i 2015. 


\section{Hovedfunn fra rapporten om tillbakemelding og oppfølging}

I utredningen «Personal feedback and advising in Norwegian higher education: Explaining student dissatisfaction» ${ }^{1}$, stilte vi tre hovedspørsmål. 1) Hvorfor er norske studenter misfornøyde med tilbakemelding og veiledning? 2) Hvor viktig er tilbakemelding og veiledning for studentene når de vurderer sin overordnede tilfredshet? 3) Hvorfor er studentene generelt tilfreds med den overordnede kvaliteten når de er misfornøyde med faktorer som forskning viser er viktig for studentenes læringsutbytte (tilbakemelding og veiledning)?

En gjennomgang av forskningslitteraturen på tilbakemelding og veiledning i høyere utdanning viser at gode formative tilbakemeldinger "facilitate students' development as independent learners who are able to monitor, evaluate, and regulate their own learning" (Evans 2013 p. 72; se også Shute 2008; Black og William 2009; Hattie og Timperley 2007; Nicol og Macfarlane-Dick 2006). Positive tilbakemeldinger kan også øke studentenes interesse og motivasjon til problemløsning og sannsynligvis gjennomføring av studier (Wigfield og Eccles 2000; Nicol og Macfarlane-Dick 2006).

I tillegg til tilbakemelding, har veiledning (interaksjon mellom studenter og faglig ansatte) positive effekter på studentenes læringsutbytte, personlig utvikling og overordnet tilfredshet med studiene (Astin 1993; Kuh og Hu 2001; Bjorklund et al; Endo og Harpel 1982; Thompson 2001; Kuh 1995; Pascarella og Terennzini 1980, Tinto 1987). Tinto (1987) fant også at kvaliteten i interaksjonen mellom studenter og faglig ansatte er en sentral faktor for redusere frafall blant studenter (se Hovdehaugen og Aamodt 2005 for et lignende funn basert på norske forhold).

Satt opp mot internasjonale forskningsfunn er resultatene fra vår rapport meget interessante. Basert på kvantitative analyser og gruppeintervjuer med studenter, faglig ansatte og programledere ved sju studieprogrammer ved Norges teknisk-vitenskapelige universitet, Universitet i Oslo, Høgskolen i Oslo og Akershus og Høgskolen i Sør-Trøndelag konkluderte vi med at studentene er misfornøyde med tilbakemelding og veiledning fordi de mottar lite av begge deler. I tillegg opplever studentene at tilbakemeldingene og veiledningen de får ikke bidrar nevneverdig til læringsutbyttet deres. Samtidig fant vi at norske studenter i liten grad forventer å få konstruktive tilbakemeldinger og veiledning, og at de i liten grad er klar over hvor positivt tilbakemeldinger og veiledning kan være for eget læringsutbytte. Studentenes lave forventninger og mangel på forståelse av viktigheten av tilbakemelding og veiledning gjør at de ikke tar hensyn til disse faktorene når de vurderer sin overordnede tilfredshet.

Studentene på høyskolene var mest tilfredse med tilbakemelding og veiledning. ${ }^{2}$ Disse studentene opplevde også miljøet mellom faglig ansatte og studenter som bedre enn studentene på universitetene. Selv om studentene ved noen studieprogrammer var mer tilfreds med tilbakemelding og veiledning, var det tydelig at veldig få studenter opplevde at tilbakemelding og veiledning var veldig viktig for deres overordnede tilfredshet. I løpet av alle intervjuene vi gjorde, nevnte ingen studenter at tilbakemelding og/eller veiledning var viktig for deres overordnede tilfredshet. Vi hørte heller ikke noen studenter si at de hadde høye forventinger om tilbakemelding og veiledning i høyere utdanning. Studentene sa derimot enten at de ikke hadde noen forventninger til tilbakemelding og veiledning før de begynte i høyere utdanning, eller at forventningene deres var at de ikke ville få tilbakemelding og

\footnotetext{
${ }^{1}$ Rapporten er tilgjengelig på:

http://www.nokut.no/Documents/Studiebarometeret/2015/Hamberg Damen Bakken_Personal feedback and advising in NOR HE Expla ining_student_dissatisfaction_5-2015.pdf

${ }^{2}$ Sivilingeniørstudiet materialteknologi på NTNU var et hederlig unntak.
} 
veiledning. Studentene fortalte at de på videregående skole hadde blitt fortalt at man i høyere utdanning var ansvarlig for egen læring og at man ikke kan forvente personlig tilbakemelding og oppfølging. Dette er derfor faktorer studentene ikke vektlegger når de skal vurdere sin overordnede tilfredshet. Informasjonen fra intervjuene stemmer godt overens med resultater fra de kvantitative analysene. Resultatene fra regresjonsanalyser viser at tilbakemelding ikke har noen effekt på overordnet tilfredshet og at individuell oppfølging (veiledning) kun har en meget begrenset effekt. I følge intervjuer og regresjonsanalyser av data fra Studiebarometeret er engasjement, relevans og læringsutbytte viktigst for studentenes overordnede tilfredshet (se Hamberg et al. 2015).

\section{Nye spørsmål i Studiebarometeret 2015}

Intervjuene som ble gjort i forbindelse med utredningen om tilbakemelding og veiledning våren 2015 indikerte at norske studenter får få tilbakemeldinger og relativt lite veiledning. I Studiebarometeret 2013 og 2014 spurte vi om studentenes tilfredshet med tilbakemelding og individuell oppfølging, men ikke om omfanget av tilbakemeldinger eller veiledning. Vi spurte heller ikke om studentenes forventinger til tilbakemelding og veiledning.

I 2015 utviklet vi derfor en del nye spørsmål angående tilbakemelding og veiledning. De nye spørsmålene dreide seg om omfang av tilbakemelding og veiledning, tilfredshet med forskjellige typer tilbakemelding og veiledning, forventinger til tilbakemelding og veiledning og i hvilken grad tilbakemelding og veiledning er viktig for studentenes overordnede tilfredshet.

De nye spørsmålene og gjennomsnittsskårene presenteres i tabell 1. Spørsmålene om tilbakemelding og veiledning er markert med farget bakgrunn. 


\section{Tabell 1: Nye spørsmål Studiebarometeret 2015}

\begin{tabular}{|c|c|c|c|}
\hline \multicolumn{4}{|l|}{ Deskriptive tall nye spørsmål } \\
\hline Spørsmål & Svarende & Gjennomsnitt & Standardavvik \\
\hline \multicolumn{4}{|l|}{ Hvor ofte - hittil i studiet - har dü: } \\
\hline $\begin{array}{l}\text { Fått tilbakemeldinger fra faglig ansatte på skriftlig arbeid } f \phi r \text { endelig } \\
\text { innlevering }\end{array}$ & 26625 & 2,7 & 2,9 \\
\hline Fått tilbakemeldinger fra faglig ansatte etter endelig innlevert skriftlig arbeid & 26846 & 4,5 & 3,6 \\
\hline Fått tilbakemeldinger fra faglig ansatte på ikke-skriftlig arbeid & 25919 & 2,9 & 3,3 \\
\hline $\begin{array}{l}\text { Fått tilbakemeldinger fra andre studenter på skriftlig eller ikke-skriftlig } \\
\text { arbeid }\end{array}$ & 26742 & 4,5 & 3,9 \\
\hline Diskutert faglige problemstillinger med faglig ansatte & 26993 & 4,5 & 3,7 \\
\hline Diskutert din faglige utvikling/resultater med faglig ansatte & 26979 & 1,8 & 2,7 \\
\hline Snakket om ikke-faglige spørsmål med faglig ansatte & 26665 & 2,8 & 3,4 \\
\hline \multicolumn{4}{|l|}{ Hvor tilfreds er du med: } \\
\hline $\begin{array}{l}\text { Tilbakemeldingene fra faglig ansatte på skriftlig arbeid } f \phi r \text { endelig } \\
\text { innlevering }\end{array}$ & 21617 & 3,1 & 1,2 \\
\hline Tilbakemeldingene fra faglig ansatte etter endelig innlevert skriftlige arbeid & 24323 & 3,3 & 1,2 \\
\hline Tilbakemeldingene fra faglig ansatte på ikke-skriftlig arbeid & 20007 & 3,2 & 1,2 \\
\hline Tilbakemeldingene fra andre studenter på skriftlig eller ikke-skriftlig arbeid & 21909 & 3,5 & 1,1 \\
\hline Faglige diskusjoner og veiledning fra faglig ansatte & 23618 & 3,4 & 1,1 \\
\hline \multicolumn{4}{|l|}{ Hvilke forventninger hadde du til: } \\
\hline Undervisningen & 25765 & 4,3 & 1,0 \\
\hline Faglige tilbakemeldinger og veiledning & 25494 & 3,9 & 1,2 \\
\hline Det sosiale og faglige miljøet & 25635 & 4,0 & 1,1 \\
\hline Studieprogrammet generelt & 25632 & 4,3 & 0,9 \\
\hline \multicolumn{4}{|l|}{ I hvilken grad bidrar disse faktorene til din overordnede tilfredshet: } \\
\hline Faglig miljø & 25510 & 4,0 & 0,9 \\
\hline Sosialt miljø & 25395 & 3,9 & 1,0 \\
\hline Studieadministrasjon og informasjon & 24715 & 3,3 & 1,1 \\
\hline Undervisning & 25721 & 3,9 & 0,9 \\
\hline Tilbakemelding og veiledning & 25413 & 3,6 & 1,1 \\
\hline Praksis & 19356 & 3,6 & 1,4 \\
\hline Yrkesrelevans & 24538 & 4,1 & 1,0 \\
\hline Læringsutbytte & 25498 & 4,2 & 0,8 \\
\hline Eksamens og vurderingsordninger & 25209 & 3,6 & 1,0 \\
\hline Om programmet er engasjerende og utfordrende & 25574 & 4,2 & 0,9 \\
\hline Mulighet for å påvirke studieprogrammet & 23930 & 3,2 & 1,2 \\
\hline Andre faktorer & 7249 & 3,3 & 1,3 \\
\hline
\end{tabular}

\footnotetext{
${ }^{3}$ Her har vi gjort om svarkategoriene fra aldri, 1-2 ganger, 3-5 ganger 6-10 ganger og over 10 ganger til 0, 1.5, 4.5, 8 og 11 . Gjennomsnittet er altså hvor mange ganger en student har mottatt tilbakemelding.
} 
Vi ser fra resultatene at studentene generelt har mottatt relativt få tilbakemeldinger, og de er relativt misfornøyd med tilbakemeldingene de mottar. Vi ser også at de har lavere forventinger til

tilbakemeldinger enn til andre faktorer, samt at studentene selv mener at tilbakemelding og veiledning i relativt liten grad påvirker deres overordnede tilfredshet. I det neste kapittelet bruker vi disse nye spørsmålene og andre variabler for å vurdere hva som forklarer studentenes overordnede tilfredshet samt tilfredshet med tilbakemeldinger.

\section{Studiebarometeret 2015: Nye analyser}

\subsection{Overordnet tilfredshet}

Først i dette kapittelet ser vi på den overordnede tilfredsheten. Analysen er basert på 2015-tall og resultatene er meget like resultatene i rapporten om tilbakemelding og veiledning i 2015, som baserte seg på 2014-data fra Studiebarometeret. 


\begin{tabular}{|c|c|}
\hline & $\begin{array}{l}\text { Overordnet } \\
\text { tilfredshet }\end{array}$ \\
\hline Faglærer engasjerende & $\begin{array}{l}0.101 * * * \\
(0.00767)\end{array}$ \\
\hline Faglærers evne til å gjøre vanskelig stoff forståelig & $\begin{array}{c}0.0515 * * * \\
(0.00751)\end{array}$ \\
\hline Undervisning dekker pensum & $\begin{array}{l}0.0650 * * * \\
(0.00684)\end{array}$ \\
\hline Tilbakemeldinger på ditt arbeid (tilfredshet med) & $\begin{array}{l}-0.0110^{*} \\
(0.00604)\end{array}$ \\
\hline Faglig oppfølging/veiledning (tilfredshet med) & $\begin{array}{c}0.0571 * * * \\
(0.00688)\end{array}$ \\
\hline Omfang tilbakemeldinger & $\begin{array}{c}0.00135 \\
(0.000855)\end{array}$ \\
\hline Omfang veiledning & $\begin{array}{l}-0.00221 * * * \\
(0.000781)\end{array}$ \\
\hline Indeks læringsmiljø & $\begin{array}{l}0.158 * * * \\
(0.00988)\end{array}$ \\
\hline Indeks medvirkning & $\begin{array}{c}0.0850 * * * \\
(0.00663)\end{array}$ \\
\hline Indeks engasjement & $\begin{array}{l}0.361 * * * \\
(0.0100)\end{array}$ \\
\hline Indeks relevans & $\begin{array}{l}0.173 * * * \\
(0.00847)\end{array}$ \\
\hline Indeks eksamen & $\begin{array}{l}-0.00323 \\
(0.00888)\end{array}$ \\
\hline Indeks læringsutbytte & $\begin{array}{l}0.154 * * * \\
(0.0112)\end{array}$ \\
\hline Kvinne & $\begin{array}{c}-0.0256^{* *} \\
(0.0108)\end{array}$ \\
\hline Alder & $\begin{array}{c}-0.00393 * * * \\
(0.000801)\end{array}$ \\
\hline Studieprogresjon & $\begin{array}{l}-0.000101 \\
(0.000120)\end{array}$ \\
\hline Programstørrelse & $\begin{array}{c}0.000191 * * * \\
(4.17 \mathrm{e}-05)\end{array}$ \\
\hline Institusjonsst $\varnothing$ rrelse & $\begin{array}{c}-0.0166 * * \\
(0.00646)\end{array}$ \\
\hline Institusjonstype & $\begin{array}{c}-0.0230 * * * \\
(0.00666)\end{array}$ \\
\hline Constant & $\begin{array}{l}-0.294 * * * \\
(0.0564)\end{array}$ \\
\hline Observasjoner & 18,599 \\
\hline R-squared & 0.492 \\
\hline $\begin{array}{l}\text { Standard error i parentes } \\
* * * \mathrm{p}<0,01, * *<0,05, *<0,1\end{array}$ & \\
\hline
\end{tabular}

Hovedpoenget med denne analysen er å vise at tilbakemelding og veiledning ikke påvirker studentenes overordnede tilfredshet. Som vi ser fra de markerte variablene i tabellen, er ikke omfang av tilbakemeldinger statistisk signifikant og tilfredshet med tilbakemeldinger er bare signifikant på 0,1- 
nivå. Selv om veiledningsvariablene er statistisk signifikante, så er de ikke substansielt signifikante, da påvirkningen deres er svært lav (og mye lavere enn de aller fleste andre variablene) og da nesten alle variabler er signifikante når antall observasjoner er så stort. Forskjellen fra fjorårets rapport er at vi her inkluderer omfang av tilbakemelding og veiledning, men heller ikke disse variablene påvirker studentenes overordnede tilfredshet.

Fjorårets rapport og årets analyser viser at studentene får relativt få tilbakemeldinger og lite veiledning og at studentene er relativt misfornøyde med begge deler, samt at studentene ikke reflekterer over dette når de vurdere sin overordnede tilfredshet. Det er likevel til dels store variasjoner på utdanningstypenivå, institusjonsnivå og individnivå på disse variablene. På studieprogramnivå varierer tilfredshet med tilbakemelding fra 1,6 til 4,8, tilfredshet med faglig oppfølging/veiledning varierer fra 1,6 til 5,0. Antall tilbakemeldinger hittil i studie varierer fra 0,6 til 22 tilbakemeldinger og antall veiledninger varierer fra 1,6 til 26,3. Variasjonen på utdanningstypenivå er også stor. I tabell 3 inkluderer vi de 5 utdanningstypene med høyest og lavest skår på tilfredshet med tilbakemelding.

Tabell 3: Tilbakemelding og veiledning per utdanningstype (topp og bunn)

\begin{tabular}{lcccc}
\hline Utdanningstype & $\begin{array}{l}\text { Tilfredshet } \\
\text { tilbakemelding }\end{array}$ & $\begin{array}{c}\text { Tilfredshet } \\
\text { oppfølging }\end{array}$ & $\begin{array}{l}\text { Antall } \\
\text { tilbakemeldinger }\end{array}$ & $\begin{array}{l}\text { Antall } \\
\text { veiledninger }\end{array}$ \\
\hline POLITI & 4,1 & 4,0 & 17,4 & 17,2 \\
\hline ARKITEKTUR & 4,0 & 3,8 & 14,0 & 15,1 \\
\hline KUNST & 3,9 & 3,7 & 12,7 & 14,2 \\
\hline SPRÅK & 3,9 & 3,6 & 9,0 & 8,6 \\
\hline HIST-FIL & 3,8 & 3,6 & 9,1 & 9,9 \\
\hline SIVING & 3,2 & 3,3 & 10,8 & 8,6 \\
\hline INGENIOR & 3,2 & 3,2 & 9,6 & 8,2 \\
\hline ODONTOLOGI & 3,1 & 3,2 & 8,5 & 14,0 \\
\hline PSYKOLOGI & 2,9 & 2,9 & 7,6 & 7,4 \\
\hline MEDISIN & 2,6 & 2,6 & 6,7 & 10,0 \\
\hline
\end{tabular}

Som vi ser fra tabellen, er det generelt «prestisje-utdanninger» som skårer svakt på alle disse variablene. Siden vi vet fra forskning at tilbakemelding og individuell oppfølging er meget viktig i høyere utdanning så er det viktig å finne ut av hva som forklarer disse relativt store forskjellene. Basert på de nye spørsmålene i Studiebarometeret 2015 kan vi nå gjøre bedre analyser på dette området enn hva som har vært mulig tidligere.

\subsection{Tilfredshet med tilbakemeldinger}

Basert på både nye og gamle spørsmål i Studiebarometeret har vi kjørt flere regresjonsanalyser for å forklare variasjonen i studentenes tilfredshet med tilbakemelding. Vi viser resultatene fra disse analysene i figurene nedenfor. 
Figur 1: Regresjonsanalyse (avhengig variabel er tilfredshet med tilbakemeldinger)

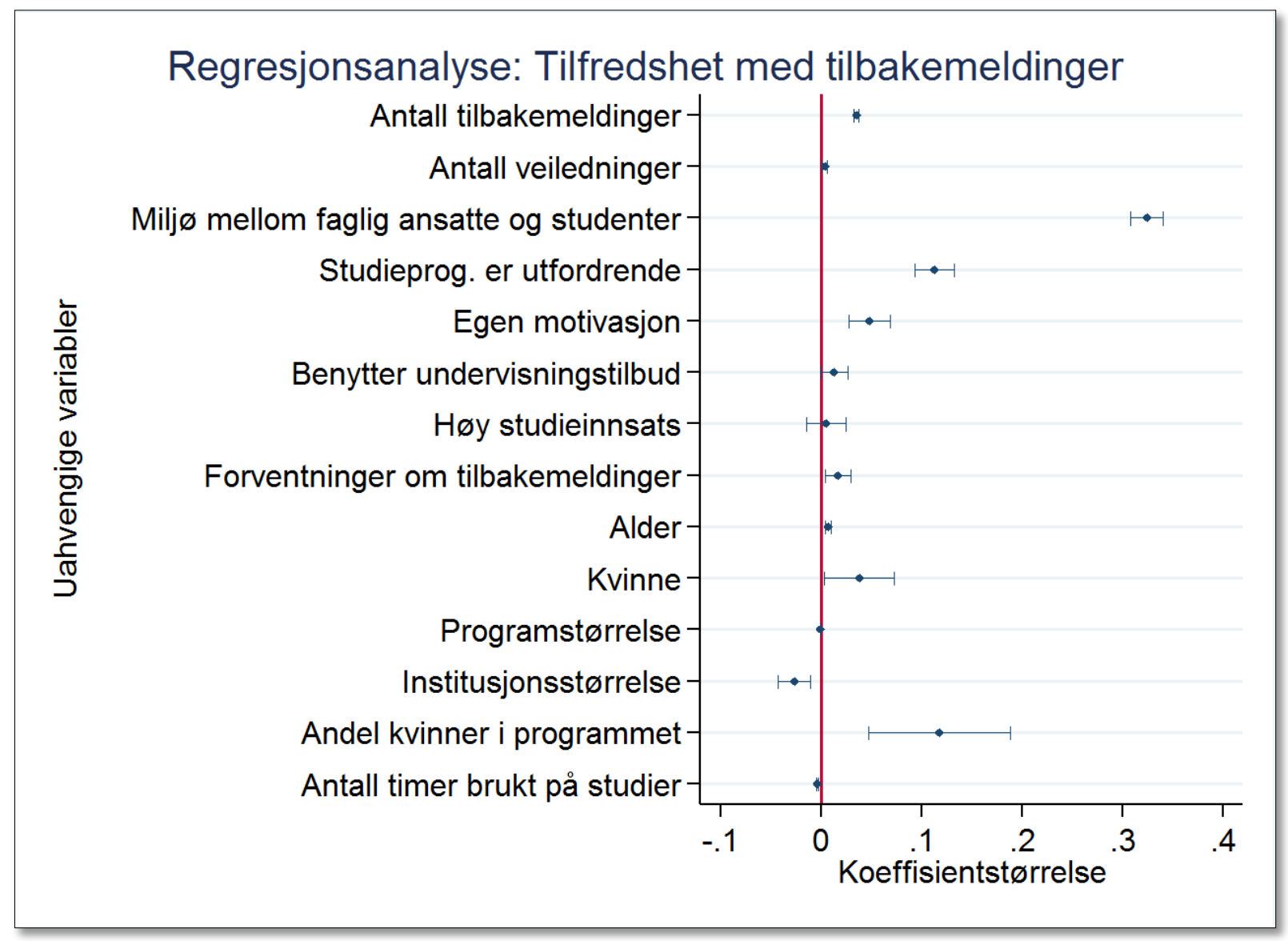

Figur 1 viser koeffisientstørrelsen for de forskjellige variablene. Linjene på hver side av punktene illustrerer $95 \%$ konfidensintervall. En variabel er statistisk signifikant hvis konfidensintervallet ikke krysser 0. Som vi ser av figuren, er miljøet mellom faglig ansatte og studenter den klart viktigste faktoren. ${ }^{4}$ Koeffisientstørrelsen er på 0,32. Det betyr at man i gjennomsnitt er 0,32 poeng mer tilfreds med tilbakemelding per poeng mer tilfreds man er med miljøet mellom faglig ansatte og studenter. Vi illustrerer effekten i figur 2.

Av andre faktorer ser vi at antall tilbakemeldinger har en svært liten positiv effekt. Hver tilbakemelding $\varnothing$ ker tilfredsheten med tilbakemeldinger med 0,03. En interessant sammenheng fremkommer dersom vi analyserer antall tilbakemeldinger og miljøet mellom faglig ansatte og studenter. Vi viser effekten av denne sammenhengen i figur 3.

I tillegg til de to nevnte faktorene er studenter som går på utfordrende studieprogrammer mer tilfreds med tilbakemeldinger og kvinner er litt mer tilfreds enn menn. Programstørrelse har ingen effekt, men institusjonsstørrelse har en liten negativ (ikke substansiell) effekt. Andelen kvinner i studieprogrammet har en positiv effekt, mens hvor mange timer studenter bruker på studier ikke har noen substansiell effekt.

\footnotetext{
${ }^{4}$ Spørsmålsformuleringer er «Hvor tilfreds er du med miljøet mellom studentene og de faglig ansatte på Studieprogrammet?».
} 
Figur 2: Effekt av miljø mellom faglig ansatte og studenter

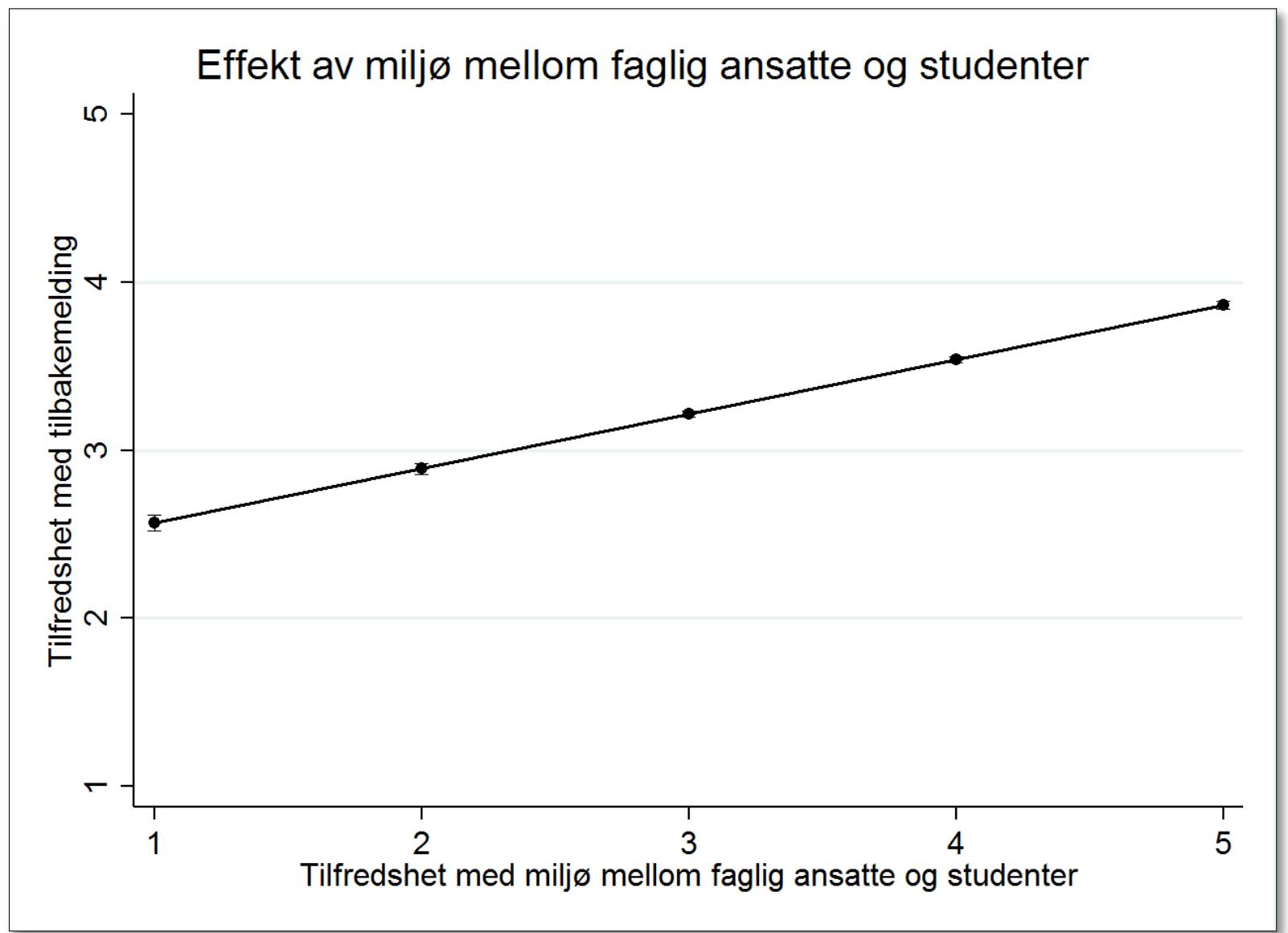

Figuren viser tydelig at jo bedre miljøet mellom faglig ansatte og studenter er, jo mer tilfreds er studenter med tilbakemeldingene. Det er likevel viktig å se denne relasjonen i sammenheng med det antallet tilbakemeldinger studentene får. Vi ser på dette forholdet i figur 3. 
Figur 3: Effekt av interaksjonen mellom miljø og antall tilbakemeldinger

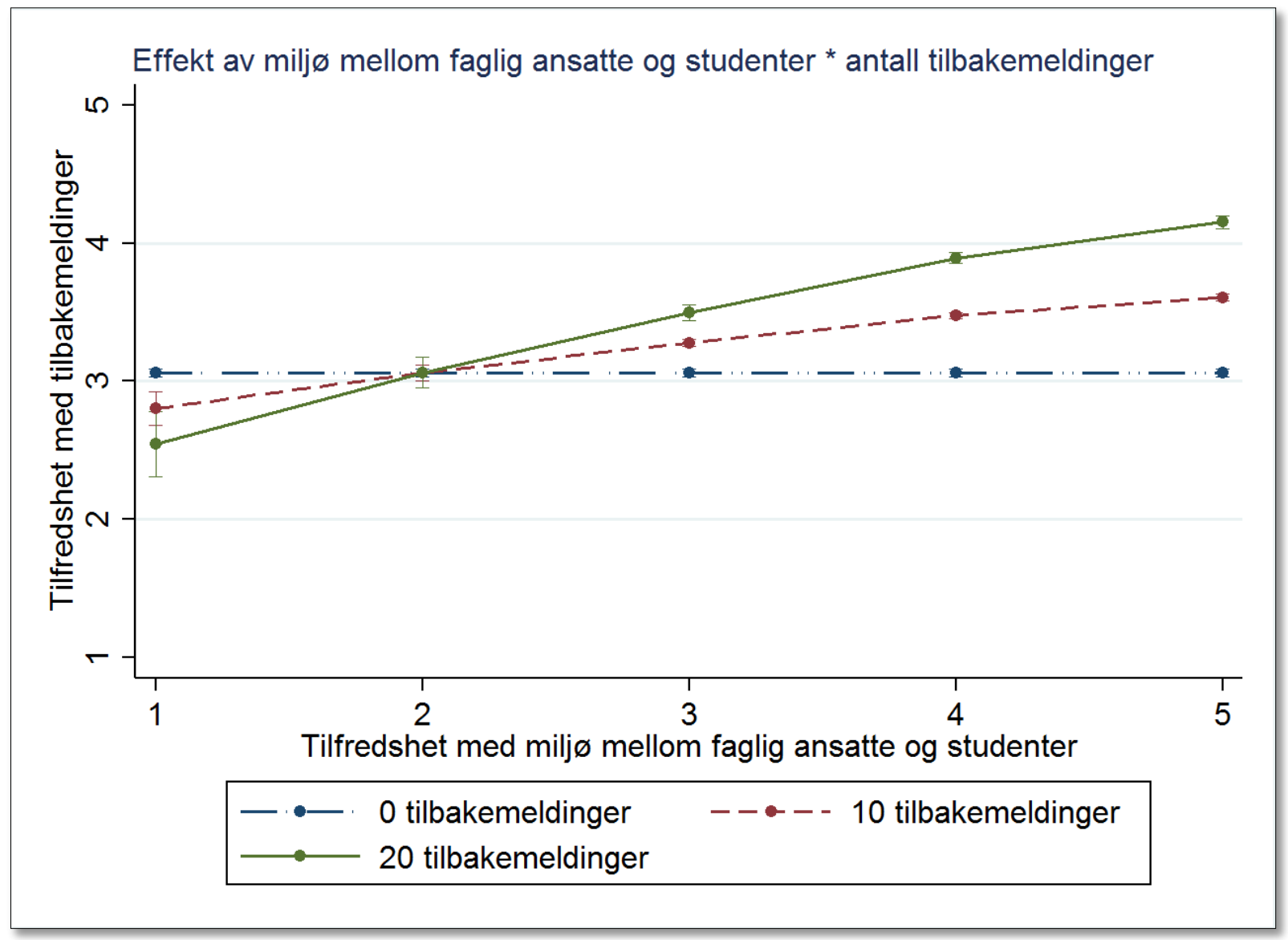

Figur 3 viser effekten av interaksjonen mellom miljø og antall tilbakemeldinger. Vi ser at effekten av flere tilbakemeldinger er avhengig av hvor godt miljøet mellom faglig ansatte og studenter er. Når miljøet er dårlig, spiller det ingen rolle hvor mange tilbakemeldinger studentene får. De er uansett lite tilfreds med tilbakemeldingene. Ettersom miljøet blir bedre, har derimot antall tilbakemeldinger en relativt stor effekt. Studenter som er tilfreds med miljøet (4 eller 5) og som får mange tilbakemeldinger (20) er også tilfreds med tilbakemeldingene de får. Dette er ikke merkelig, for et godt miljø mellom faglig ansatte og studenter påvirker både studenter og faglig ansatte. Faglig ansatte får mer eierskap i studentenes læringsutbytte, involverer studentene mer og bidrar til at studentene forstår de positive effektene tilbakemeldinger kan ha. Studentene, på sin side, vil søke mer formative tilbakemeldinger og bruke disse for å bedre sitt eget læringsutbytte. Et klart råd til institusjonene er dermed at de ikke bare bør gi flere tilbakemeldinger, men også jobbe med å forbedre miljøet mellom studentene og de faglig ansatte.

I tillegg til analysene som er presentert har NOKUT kjørt både ordinære og multilevel regresjonsanalyser med omfang av faglige tilbakemeldinger som avhengig variabel. Også her har miljøet blant studenter og ansatte størst påvirkning, mens engasjerte faglærere har nest størst effekt. Programstørrelse har ikke en signifikant effekt, men institusjonsstørrelse har en svak negativ og signifikant effekt. 


\section{Tilbakemelding og veiledning på NTNU}

Analysene over stemmer veldig godt overens med intervjuene vi gjorde på studieprogrammer på fire institusjoner våren 2015, deriblant på Høgskolen i Sør-Trøndelag (HiST) og Norges tekniskvitenskapelige universitet (NTNU). I de studieprogrammene som skåret relativt godt på tilbakemeldinger var det tydelig at miljøet mellom faglig ansatte og studenter var godt, studieprogrammene var relativt små og studentene fikk en god del formativ tilbakemelding på arbeidet sitt. Etter årets fusjon mellom NTNU, HiST, og høyskolene i Gjøvik og Ålesund (HiG og HiÅ) er det interessant å sammenligne en del lignende studier som finnes på alle fire institusjonene (campusene). I resten av dette notatet ser vi derfor på ingeniørstudiene ved alle institusjonene. Dette inkluderer både sivilingeniørstudier og bachelorgrader i ingeniørfag.

I dette kapitlet bruker vi data fra 2015 og sammenligner kun svarene fra 2. års studenter. Dersom vi inkluderer svarene fra studentene på 5. studieår, endrer gjennomsnittene seg i svært liten grad, på tross av deres betydelig lengre erfaring som studenter. ${ }^{5}$

Figur 4 viser gjennomsnittsskåren på tilfredshet med tilbakemelding, oppfølging/veiledning og overordnet tilfredshet på de fire institusjonene.

Figur 4: Opplevd kvalitet på tilbakemelding og oppfølging blant 2. års studenter i ingeniør- og sivilingeniørstudier: Gjennomsnittsskår per institusjon

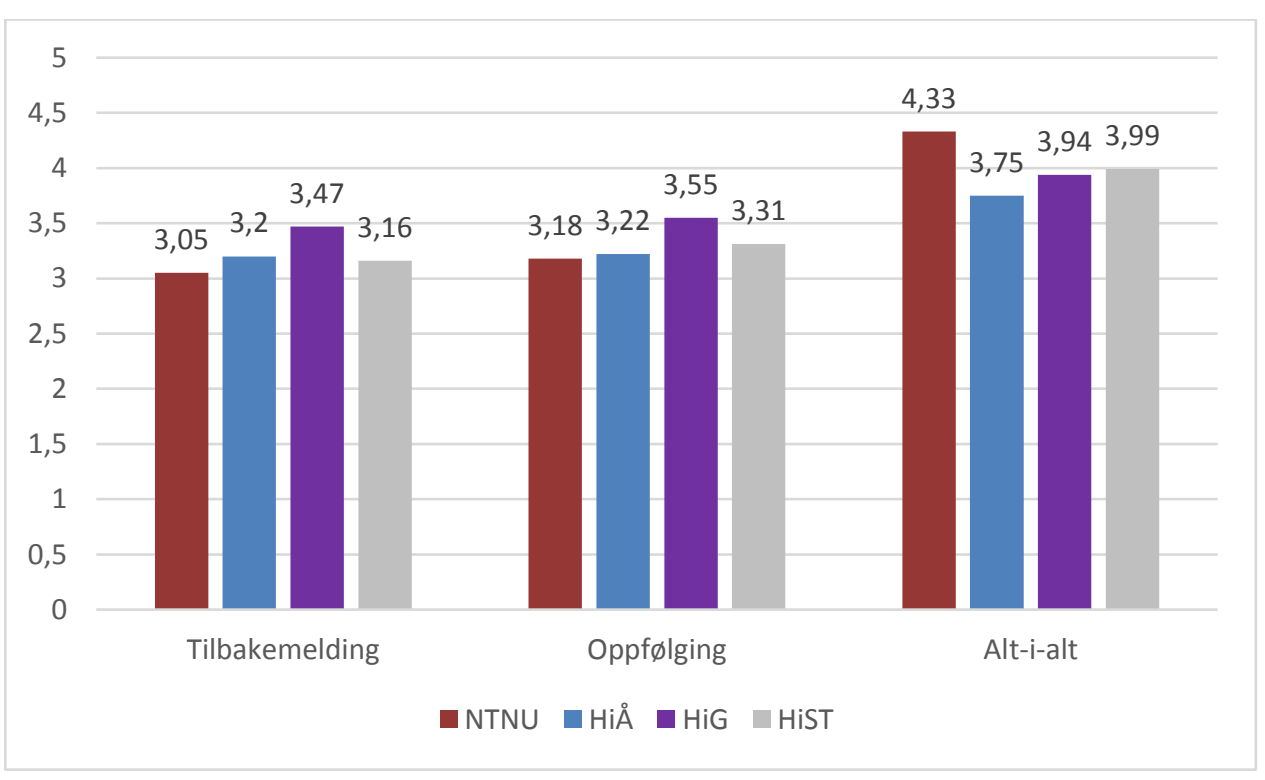

NTNU skårer lavest på tilbakemelding og oppfølging, men høyest på overordnet tilfredshet (alt-i-alt). Forskjellene er ikke veldig store på institusjonsnivå og langt fra alle forskjellene er statistisk signifikante. På tilbakemelding og oppfølging er det kun forskjellen mellom NTNU og HiG som er statistisk signifikant, mens på overordnet tilfredshet er forskjellen mellom NTNU og alle andre 
institusjoner statistisk signifikant. Forskjellen mellom de andre institusjonene er ikke statistisk signifikant.

Forskjellen på antall tilbakemeldinger er heller ikke stor og varier fra 9,2 til 11,4. Disse forskjellene er ikke statistisk signifikante. Forskjellen på antall veiledninger er noe større og her rapporterer NTNUstudentene at de får mange færre veiledninger enn de andre studentene. Forskjellen mellom NTNU og de andre er statisk signifikant, men forskjellen mellom høyskolene er ikke statistisk signifikant.

Figur 5 viser gjennomsnittsskåren på omfanget av tilbakemelding og oppfølging/veiledning på de fire institusjonene.

Figur 5: Omfang av tilbakemelding og oppfølging blant 2. års studenter i ingeniør- og sivilingeniørstudier: Gjennomsnittsskår per institusjon

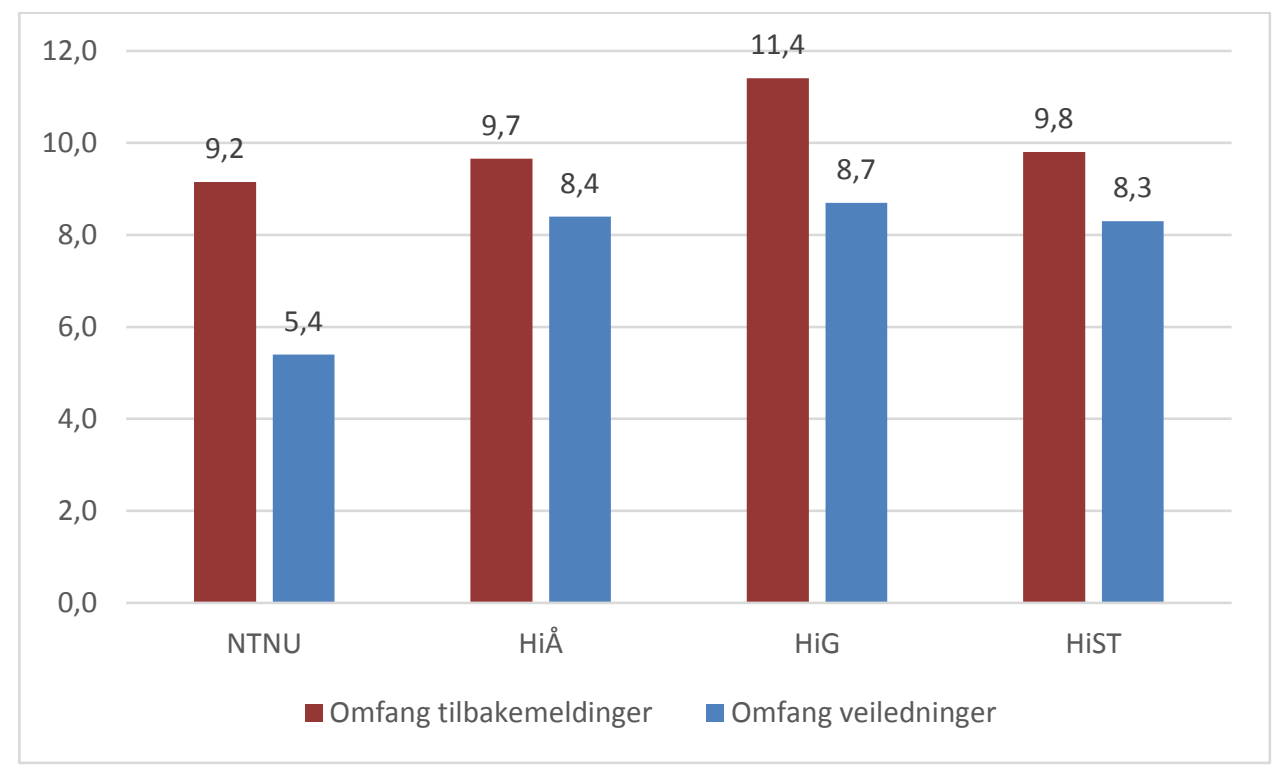

Bortsett fra antall veiledninger er altså forskjellene ganske små på institusjonsnivå når det gjelder tilbakemelding og veiledning. Hva så på programnivå? Og hvordan opplever studentene miljøet mellom faglig ansatte og studenter? I tabell 4 lister vi opp de fem programmene med de mest tilfredse studentene når det gjelder tilbakemelding og de fem programmene med de minst tilfredse studentene. ${ }^{6}$

${ }^{6}$ Se vedlegg 1 for resultatene til alle ingeniørprogrammene ved NTNU. 
Tabell 4: Tilfredshet med og omfang av tilbakemelding og oppfølging blant 2. års studenter på noen programmer: Gjennomsnittsskår per ingeniør- og sivilingeniørprogram

\begin{tabular}{|c|c|c|c|c|c|c|c|c|}
\hline Institusjon & Studieprogram & $\begin{array}{l}\text { Antall } \\
\text { svarende * }\end{array}$ & $\begin{array}{l}\text { Tilfredshet } \\
\text { med } \\
\text { tilbakemelding }\end{array}$ & $\begin{array}{l}\text { Tilfredshet } \\
\text { med } \\
\text { oppfølging }\end{array}$ & $\begin{array}{l}\text { Tilfredshet } \\
\text { med miljø }\end{array}$ & $\begin{array}{l}\text { Overordnet } \\
\text { tilfredshet }\end{array}$ & $\begin{array}{l}\text { Antall } \\
\text { tilbake- } \\
\text { meldinger }\end{array}$ & $\begin{array}{l}\text { Antall } \\
\text { veiled- } \\
\text { ninger }\end{array}$ \\
\hline NTNU & $\begin{array}{l}\text { Materialteknologi - } \\
\text { masterstudium (5- } \\
\text { årig) }\end{array}$ & 10 & 3,9 & 3,5 & 4,8 & 4,4 & 17,6 & 11,0 \\
\hline HiST & $\begin{array}{l}\text { Bachelor i } \\
\text { ingeniørfag, } \\
\text { materialteknologi }\end{array}$ & 34 & 3,9 & 3,7 & 3,9 & 4,2 & 16,6 & 8,0 \\
\hline HiST & $\begin{array}{l}\text { Bachelor i } \\
\text { ingeniørfag, } \\
\text { fornybar energi }\end{array}$ & 28 & 3,7 & 3,6 & 4,0 & 4,2 & 13,8 & 13,5 \\
\hline $\mathrm{HiG}$ & $\begin{array}{l}\text { Bachelor i } \\
\text { ingeniørfag - } \\
\text { maskin }\end{array}$ & 24 & 3,7 & 3,5 & 3,4 & 4,0 & 12,3 & 7,0 \\
\hline $\mathrm{HiG}$ & $\begin{array}{l}\text { Bachelor i } \\
\text { ingeniørfag - elektro }\end{array}$ & 15 & 3,6 & 3,6 & 3,9 & 4,0 & 12,2 & 10,2 \\
\hline NTNU & $\begin{array}{l}\text { Bygg- og } \\
\text { miljøteknikk - } \\
\text { masterstudium (2- } \\
\text { årig) }\end{array}$ & 27 & 2,8 & 3,2 & 3,4 & 3,8 & 7,8 & 7,5 \\
\hline NTNU & $\begin{array}{l}\text { Bygg- og } \\
\text { miljøteknikk - } \\
\text { masterstudium (5- } \\
\text { årig) }\end{array}$ & 61 & 2,8 & 3,1 & 3,5 & 4,5 & 6,8 & 3,9 \\
\hline HiST & $\begin{array}{l}\text { Bachelor i } \\
\text { ingeniørfag, maskin }\end{array}$ & 68 & 2,6 & 2,9 & 3,0 & 3,3 & 5,6 & 5,6 \\
\hline NTNU & $\begin{array}{l}\text { Marin teknikk - } \\
\text { masterstudium ( } 2 \text { - } \\
\text { årig) }\end{array}$ & $6 * *$ & 2,5 & 2,8 & 3,3 & 3,0 & 7,4 & 12,0 \\
\hline NTNU & $\begin{array}{l}\text { Industriell økonomi } \\
\text { og teknologiledelse - } \\
\text { masterstudium (5- } \\
\text { årig) }\end{array}$ & 51 & 2,5 & 2,7 & 3,6 & 4,4 & 8,8 & 4,2 \\
\hline
\end{tabular}

* Svarprosenten ligger mellom $34 \%$ og $94 \%$ for de 10 programmene, gjennomsnitter er $57 \%$.

** Svarprosenten er på $67 \%$, altså har 6 av 9 studenter besvart spørreskjemaet.

Tallene over er interessante av flere årsaker. For det første ser vi at fire av de fem programmene hvor studentene er mest tilfreds med tilbakemelding er på en av de innfusjonerte høyskolene, mens fire av de fem programmene hvor studentene er minst tilfreds med tilbakemeldinger er på NTNU. Det er også interessant å merke seg at studentene ved et av NTNUs prestisjeprogrammer (Industriell økonomi og teknologiledelse) har de minst fornøyde studentene på spørsmålet om tilbakemeldinger.

Tallene i tabellen gjenspeiler analysen over meget godt; programmene på toppen av listen skårer generelt høyt på miljø mellom studenter og faglig ansatte, og studentene får mange flere tilbakemeldinger enn studenter på programmene på bunn.

Ved å inkludere femte års studenter på de tre 5-årige sivilingeniørstudiene, endrer verdiene seg noe for noen av programmene. For Industriell økonomi øker tilbakemelding til 2,8, mens miljø synker til 3,3. For Bygg og miljøteknikk 5-årig endres verdiene bare marginalt. For Materialteknologi endres et par 
av verdiene noe mer; spørsmålet om tilbakemelding synker til 3,6, og spørsmålet om miljø synker til 4,4 - de mest erfarne studentene er altså mer misfornøyde enn studentene på 2. studieår.

Disse tallene stemmer også meget godt med de intervjuene vi gjorde på NTNU og HiST våren 2015. Vi intervjuet studenter, faglærere og programansvarlige på materialteknologi på HiST og NTNU, og intervjuene indikerte at en viktig faktor for studentenes tilfredshet var det gode miljøet mellom de faglig ansatte og studentene. Når det gjaldt programmer vi intervjuet som gjorde det relativt dårlig med hensyn til tilbakemeldinger (ingen av de fem dårligste i tabellen over), fant vi ofte det motsatte; studenter kjente knapt noen faglig ansatte, det var få tilbakemeldinger, og mye av arbeidet studentene gjorde føltes bortkastet siden de ikke fikk tilbakemelding, eller konstruktive tilbakemeldinger, på det. Flere studenter sa for eksempel at de aldri hadde vært innom kontoret til professorer i kontortiden etc.

Tallene fra NTNU viser at med all tydelighet at det er mye å gå på med tanke på tilbakemelding og veiledning for mange studieprogrammer. Det er også tydelig at «gamle» NTNU her kan lære noe av de innfusjonerte høyskolene. Forskningen viser at tilbakemelding og veiledning er sentralt for å $\emptyset$ ke studenters motivasjon, læringsutbytte, personlig utvikling og overordnet tilfredshet. Dette er viktige faktorer tidlig i studentenes løp. I tilbakemeldingsrapporten fra 2015 konkluderte NOKUT med at studentene mangler forståelse for hvor viktig tilbakemeldinger kan være for deres egen utvikling og læring, og da hjelper det lite å si at studentene våre får mer tilbakemelding og oppfølging i de siste studieårene sine. Kanskje er det til og med viktigst å ha fokus på tilbakemelding og oppfølging tidlig i studieløpet, for å inkludere ferske studenter kjappest og best mulig i akademia og for å tidligst mulig $\emptyset$ ke motivasjon, læring og redusere frafall.

\section{Konklusjon}

Utgangspunktet for NOKUTs utredning om tilbakemelding og veiledning i høyere utdanning var det interessante paradokset at selv om studentene er misfornøyd med tilbakemelding og individuell oppfølging så er de meget tilfredse med kvaliteten i studieprogrammet sine. Dette er spesielt interessant når vi vet at formative tilbakemeldinger og individuell oppfølging har positive effekter på studentenes tilegnelse av kunnskap og ferdigheter, læring, motivasjon, studiegjennomføring og overordnet tilfredshet. Basert på intervjuer på sju studieprogrammer konkluderte vi med at studentene har lave forventninger til tilbakemeldinger og veiledning. I tillegg mangler de forståelse for hvor viktig disse faktorene er for deres egen læring og motivasjon.

I utredningen fra 2015 konkluderte NOKUT med at studentene er misfornøyd med tilbakemelding og veiledning fordi de får få tilbakemeldinger og fordi tilbakemeldingene sjelden er konstruktive. Basert på funnene i utredningen inkluderte vi flere nye spørsmål i Studiebarometeret 2015. Analysene i dette notatet viser at funnene fra fjorårets utredning fortsatt gjelder. Studentene er misfornøyd med tilbakemelding og veiledning, men den overordnede tilfredsheten er høy. Basert på nye tall og analyser kan vi nå slå fast at antall tilbakemeldinger og miljøet mellom faglig ansatte og studenter er faktorer som forklarer mye av studentenes lave tilfredshet med tilbakemeldinger.

Det at studentenes lave tilfredshet med tilbakemelding og veiledning ikke påvirker den overordnede tilfredsheten bør ikke fungere som en sovepute for institusjonene. Studentenes mangel på forståelse av hvor viktig tilbakemelding og veiledning er, bør heller føre til at institusjonene gir flere og bedre tilbakemeldinger og veiledninger. De bør også gjøre studentene oppmerksomme på den verdien gode 
tilbakemeldinger og veiledning har for studentenes læringsutbytte. Dette fokuset bør starte allerede i første studieår.

På NTNU er det tydelig at de innfusjonerte høyskolene har hatt mer fokus på tilbakemelding og veiledning enn studieprogrammene ved «gamle» NTNU. Det er noen naturlige årsaker til dette: mindre studieprogram, mer fokus på undervisning enn forskning, og færre master- og doktorgradsstudenter. Vi tror likevel at tallenes klare tale indikerer at faglig ansatte og undervisningsledere ved «gamle» NTNU har noe å lære av de innfusjonerte høyskolene. 